\title{
The Replication, Partition and yop Regulation of the pYV Plasmids Are Highly Conserved in Yersinia enterocolitica and $Y$. pseudotuberculosis
}

\author{
By THIERRY BIOT AND GUY R. CORNELIS* \\ Unité de Microbiologie, Université Catholique de Louvain, UCL 54.90, \\ B1200 Brussels, Belgium
}

(Received 19 November 1987; revised 12 February 1988)

\begin{abstract}
The replication genes (rep) of the virulence plasmid pYVe439-80 of Yersinia enterocolitica were localized and characterized by restriction endonuclease analysis. Comparison with pIB1, a virulence plasmid of $Y$. pseudotuberculosis, indicates that while the plasmids carry homologous rep genes their location with respect to the highly conserved 'calcium region' is different. This replication function is thermosensitive. Mini-derivatives of pYVe439-80 appear to be rather unstable. The region of pYVe439-80 containing homology to the incD determinant of $F$ was shown to contain a plasmid-stabilization system (par). The region encoding par was characterized by restriction endonuclease analysis. pIB1 contained an homologous par region but located differently. The pYV plasmids thus underwent rearrangements during their divergent evolution. While the positions of rep and par in the two plasmids are inverted with respect to the surrounding loci, our determination of the orientation of each locus rules out the hypothesis of a simple inversion of a quadrant of pYV. The gene encoding YOP5, a $26 \mathrm{kDa}$ protein encoded by pIB1, was cloned on a mobilizable vector and introduced in Y. enterocolitica W22708 containing pYVe227 (indistinguishable from pYVe439-80), mutated in the homologous gene. The recombinant $Y$. enterocolitica secreted YOP5. Hence, the transcriptional activation and secretion systems of pYVe227 act on a yop gene from pIB1 and on its product, indicating that these systems are interchangeable.
\end{abstract}

\section{INTRODUCTION}

Pathogenic species of the genus Yersinia (Y.enterocolitica, Y.pseudotuberculosis and Y.pestis) cause human diseases, with symptoms ranging from enteritis to septicaemia and death, essentially by invading the host tissues. The clinical manifestations of $Y$. enterocolitica infections in man are mostly enteric. The predominant clinical features are abdominal pain, sometimes evoking an appendicitis, and diarrhoea.

The three species carry plasmids of about $70 \mathrm{~kb}$ that appear to be necessary for virulence (Gemski et al., 1980a, b; Zink et al., 1980; Ferber \& Brubaker, 1981; Bakour et al., 1985). These plasmids, generally called pYV plasmids, cause a requirement for calcium for growth at $37^{\circ} \mathrm{C}$ : pYV-containing yersiniae form colonies at $28^{\circ} \mathrm{C}$ but not at $37^{\circ} \mathrm{C}$ on media deprived of calcium, while bacteria cured of pYV plasmids or carrying a mutated plasmid grow at both temperatures on oxalated media (see Cornelis et al., 1987b).

In conditions of growth restriction, i.e. at $37^{\circ} \mathrm{C}$ in the absence of calcium, pYV plasmids from $Y$. enterocolitica and $Y$. pseudotuberculosis direct the secretion of at least nine proteins (Heesemann et al., 1984; Cornelis et al., 1987a). Some of these proteins are also inserted in the outer membrane (Portnoy et al., 1984), which explains why these proteins are currently referred to as 'YOPs', for 'Yersinia outer membrane proteins'. The structural genes of these proteins (yop genes) are scattered around the pYV plasmids (Cornelis et al., 1987 a; Forsberg et al., 1987). At least four transcriptional loci, spanning a contiguous $17 \mathrm{~kb}$ region and called $\operatorname{vir} A$, vir $B$, vir $C$ and vir $F$, control the calcium response and the production of the YOPs. Gene vir $F$ encodes a trans- 
acting transcription activator. The functions of vir $A, B$ and $C$ are not yet known (Cornelis et al., $1986,1987 a$ ). The region controlling the calcium response is highly conserved in the pYV plasmids from Y. enterocolitica, Y.pseudotuberculosis and Y.pestis (Goguen et al., 1984; Portnoy et al., 1984; Cornelis et al., 1986). However, the yop genes are distributed differently in these plasmids (Straley \& Bowmer, 1986; Cornelis et al., 1987a; Forsberg et al., 1987).

The replication functions are also located differently in the pYV plasmid from $Y$. enterocolitica (Bakour et al., 1983; Portnoy et al., 1984) as compared with the pYV plasmids from Y.pseudotuberculosis and Y.pestis (Portnoy \& Falkow, 1981; Portnoy et al., 1984). Portnoy et al. (1984) suggested that the replication functions might be different in these two types and that a recombinational event had occurred between two ancestral plasmids, one encompassing the replication region and another encompassing the calcium-dependence region. The pYV plasmids from $Y$. enterocolitica and $Y$. pseudotuberculosis both belong to the incompatibility group FI. The only determinant they have in common with $\mathrm{F}$ is inc $D$. This determinant could be part of a partition system analogous to that of $F$ (Bakour et al., 1983). The present work is mainly devoted to the ancillary functions of pYV, namely replication and partition.

\section{METHODS}

Bacterial strains, plasmids and growth conditions. Escherichia coli $\mathrm{C} 600$ and $\mathrm{HB} 101$ are described in Maniatis $e t$ al. (1982). E. coli JC6310 and JG112 (polA) are described in Balligand et al. (1985). Yersinia strains and plasmids are listed in Table 1.

Liquid cultures were routinely grown in tryptic soy broth (TSB) and plate cultures were on tryptic soy agar (TSA) or MacConkey agar (MC) containing the relevant selective agents at the following concentrations: ampicillin, $100 \mu \mathrm{g} \mathrm{ml}^{-1}$; kanamycin, $25 \mu \mathrm{g} \mathrm{ml}^{-1}$, merbromin, $100 \mu \mathrm{g} \mathrm{ml}^{-1}$; nalidixic acid, $35 \mu \mathrm{g} \mathrm{ml}^{-1}$; and tetracycline, $10 \mu \mathrm{g} \mathrm{ml}^{-1}$.

Table 1. Bacterial strains and plasmids

\begin{tabular}{|c|c|c|}
\hline Bacterial strain & Relevant characteristics & Reference \\
\hline $\begin{array}{l}\text { Y. enterocolitica W227 } \\
\text { Y. enterocolitica W } 22703 \\
\text { Y. enterocolitica } 439-80 \\
\text { Y. pseudotuberculosis YPIII }\end{array}$ & $\begin{array}{l}\text { Wild-type, serogroup } 9 \\
\text { Res }^{-} \text {Mod }^{+} \text {Nal }^{\mathrm{R}} \text { derivative of W227 } \\
\text { Wild-type, serogroup } 9 \\
\text { Wild-type, serogroup III }\end{array}$ & $\begin{array}{l}\text { Cornelis \& Colson (1975) } \\
\text { Cornelis \& Colson (1975) } \\
\text { Laroche et al. }(1984) \\
\text { Bölin et al. }(1982)\end{array}$ \\
\hline Plasmid & Relevant characteristics or derivation & Origin or reference \\
\hline mini-vir-kan & $\begin{array}{l}\text { BamHI fragment } 3 \text { of pYVe439-80+ } \\
\mathrm{Km}^{\mathrm{R}} \text { fragment of } \mathrm{Tn} 5\end{array}$ & Bakour et al. (1983) \\
\hline pGC653 & $\begin{array}{l}\text { Mini-vir-kan deleted from } 1.7 \mathrm{~kb} \text { BstEII } \\
\text { fragment }\end{array}$ & This study \\
\hline pGC659 & $\begin{array}{l}\text { pGC653 deleted from }(0.9 \text { kb HindIII } \\
\text { fragment }+1.1 \mathrm{~kb} B g l \text { II fragment })\end{array}$ & This study \\
\hline pGC660 & $\begin{array}{l}\text { pGC659 reduced by Tn } 501 \text { transposition } \\
\text { followed by deletion of a HindIII fragment }\end{array}$ & This study \\
\hline pGC666 & $\begin{array}{l}\text { pGC } 660 \text { deleted from } 1.7 \mathrm{~kb} S \mathrm{mal} \text { fragment; } \\
=\text { minimal replicon of pYVe } 439-80+\mathrm{Km}^{\mathrm{R}}\end{array}$ & This study \\
\hline pGC680 & pGC653 + fragment B1 of pYVe439-80 & This study \\
\hline pGC711 & $\begin{array}{l}\text { pKT279 inserted in the EcoRI site of } \\
\text { pGC666 within pYV DNA }\end{array}$ & This study site of \\
\hline $\begin{array}{l}\text { pIB1 } \\
\text { pIB588 }\end{array}$ & $\begin{array}{l}\text { pYVplasmid from } Y \text {. pseudotuberculosis YPIII } \\
\text { BamHI fragment } 4 \text { of pIB1 cloned in pBR322 }\end{array}$ & $\begin{array}{l}\text { Bölin et al. (1982) } \\
\text { Gift of I. Bölin \& H. Wolf-Watz } \\
\text { (University of Umeå) }\end{array}$ \\
\hline pKT279 & bla-negative derivative of pBR322 & Talmadge \& Gilbert (1980) \\
\hline pTB1 & $\begin{array}{l}\text { pTM } 100+E c o R I-B a m H I \text { fragment } \\
\text { of pIB588 containing yop } 5\end{array}$ & This study \\
\hline pTM100 & $\begin{array}{l}\text { pACYC184 + oriT of RP4; oriT was a } \\
\text { gift of D. Helinski }\end{array}$ & $\begin{array}{l}\text { Constructed by } \mathrm{T} \text {. Michiels } \\
\text { in this laboratory }\end{array}$ \\
\hline $\begin{array}{l}\text { pUC9-B5 } \\
\text { pYVe227 } \\
\text { pYVe439-80 } \\
\text { R388::Tn } 501\end{array}$ & $\begin{array}{l}\text { pUC9 + BamHI fragment } 5 \text { of pIB1 } \\
\text { pYV plasmid from } Y \text {. enterocolitica } \text { W227 } \\
\text { pYV plasmid from } Y \text {. enterocolitica } 439-80\end{array}$ & $\begin{array}{l}\text { This study } \\
\text { Cornelis et al. (1986) } \\
\text { Laroche et al. (1984) } \\
\text { This study }\end{array}$ \\
\hline
\end{tabular}


For the analysis of YOP proteins, yersiniae were grown in brain heart infusion supplemented with $0.4 \%$ glucose, $10 \mathrm{mM}-\mathrm{MgCl}_{2}, 10 \mathrm{mM}-\mathrm{MgSO}_{4}$ and $20 \mathrm{~mm}$-sodium oxalate (BHI-MOX). The inoculum of the culture was adjusted to an optical density $(600 \mathrm{~nm})$ of 0.1 and the cultures were incubated with shaking (150 r.p.m.) at room temperature. After $2 \mathrm{~h}$, the cultures were shifted to a $37^{\circ} \mathrm{C}$ waterbath (thermal induction) and the incubation was continued for $4 \mathrm{~h}$ with shaking. The bacteria were then centrifuged for $30 \mathrm{~min}$ at $1875 \mathrm{~g}$.

Analysis of proteins. Proteins present in the supernatant were analysed by SDS-PAGE as described in Cornelis $e t$ al. (1986).

Genetic methods. Conjugations and transformations were done as described in Balligand et al. (1985).

Plasmid stability test. A plasmid-containing colony was picked from a selective plate and grown in TSB, under selective pressure. The culture was then diluted and a volume of $100 \mu \mathrm{l}$, containing about 100 cells, was inoculated in a $100 \mathrm{ml}$ flask containing $20 \mathrm{ml}$ antibiotic-free TSB. This culture was incubated at room temperature, at $37^{\circ} \mathrm{C}$ or at $40^{\circ} \mathrm{C}$ with shaking for $40 \mathrm{~h}$. Dilutions of the culture were plated onto MC. Ninety-six colonies were picked, grown for $6 \mathrm{~h}$ in $200 \mu \mathrm{l}$ TSB and replicated onto MC containing the appropriate antibiotic to detect continued carriage of the original plasmid.

Isolation and in vitro manipulation of plasmid DNA. Plasmid DNA was prepared as described previously (Balligand et al., 1985). In vitro restriction fragment deletion, cloning, terminal labelling with DNA polymerase I (Klenow) and hybridizations were done according to Maniatis et al. (1982).

\section{RESULTS AND DISCUSSION}

\section{Accurate localization of the replication region of the $p Y V$ plasmid of $Y$. enterocolitica}

Plasmid mini-vir-kan (11.7 kb) consisted of BamHI fragment 3 (hereafter referred to as B3) from pYVe439-80, linked to the kanamycin $(\mathrm{Km})$ resistance determinant of Tn5 (Bakour et al., 1983). Mini-vir-kan was further reduced in size by BstEII digestion, ligation and transformation of $E$. coli $\mathrm{C} 600$. None of the $\mathrm{Km}^{\mathrm{R}}$ transformants had lost more than a small $1.7 \mathrm{~kb}$ fragment (i.e. $\Delta \mathrm{I}$ in Fig. 1), suggesting that replication genes or sites span the two other BstEII fragments. One of these deletants was called pGC653. pGC653 was reduced in turn to $8.0 \mathrm{~kb}$ (pGC659) by removing a $0.9 \mathrm{~kb}$ HindIII fragment (i.e. $\Delta \mathrm{II}$ in Fig. 1) and a $1.1 \mathrm{~kb} B g I I \mathrm{I}$ fragment (i.e. $\Delta \mathrm{III}$ in Fig. 1).

The extent of the replication region on the right-hand side of the BstEII site (coordinate $4.8 \mathrm{~kb}$ of pGC659) was defined by random insertion of a HindIII site followed by the excision of the HindIII fragment created by this insertion. Transposon Tn 501 was selected to apply this strategy because it contains a single HindIII site located $136 \mathrm{bp}$ from one terminus; it also contains two EcoRI sites within the inverted repeats, at $13 \mathrm{bp}$ from the termini (Brown et al., 1980; see Fig. 1). Transposition of Tn 501 was selected by the mobilization procedure: pGC659 and R388 : : Tn 501 were introduced into $E$. coli $\mathrm{C} 600$ and the latter strain was subsequently mated with nalidixicacid-resistant derivatives of $E$. coli $\mathrm{HB} 101$. Selection was applied for resistance to kanamycin, nalidixic acid and merbromin. This strategy is based on the transfer of a cointegrate plasmid (de la Cruz \& Grinsted, 1982). The resulting strain thus contains R388::Tn501 and pGC659::Tn501. The latter plasmid is separated from the former by a transformation step. All the pGC659::Tn501 derivatives were pooled. Plasmid DNA was extracted, digested with $H$ indIII, ligated and used to transform E. coli C600. Among 250 transformants, 90 were sensitive to mercuric ions, suggesting that transposition had occurred in the appropriate orientation. Among these, 37 were analysed by gel electrophoresis. The size of the smallest plasmid, called pGC660, was $5.0 \mathrm{~kb}$ (Fig. 1).

Plasmid pGC660 was reduced in size by removing the $1.7 \mathrm{~kb}$ SmaI fragment on the other side of the replication genes. The resulting plasmid, pGC666, is $3.3 \mathrm{~kb}$ long and contains $1.32 \mathrm{~kb}$ of DNA from Tn5 encompassing the neo gene (Beck et al., 1982) and $0.13 \mathrm{~kb}$ from Tn501. The minimal replicon of the virulence plasmid pYVe439-80 is hence no larger than $1.85 \mathrm{~kb}$.

Several attempts to isolate the replication genes on an EcoRI fragment of pYVe439-80 were unsuccessful (data not shown), suggesting that the essential region for replication encompasses the EcoRI site located $0.2 \mathrm{~kb}$ from the junction between pYVe439-80 DNA and Tn 5 DNA in plasmid pGC666. In order to verify this assumption, plasmid pKT279 was inserted into pGC666 at this EcoRI site after partial digestion. The recombinant plasmid, called pGC711, was used to transform, in parallel, E. coli strains C600 and JG112 (polA), the latter being a strain in which pKT279 does not replicate. Only the former strain could be transformed by pGC711 

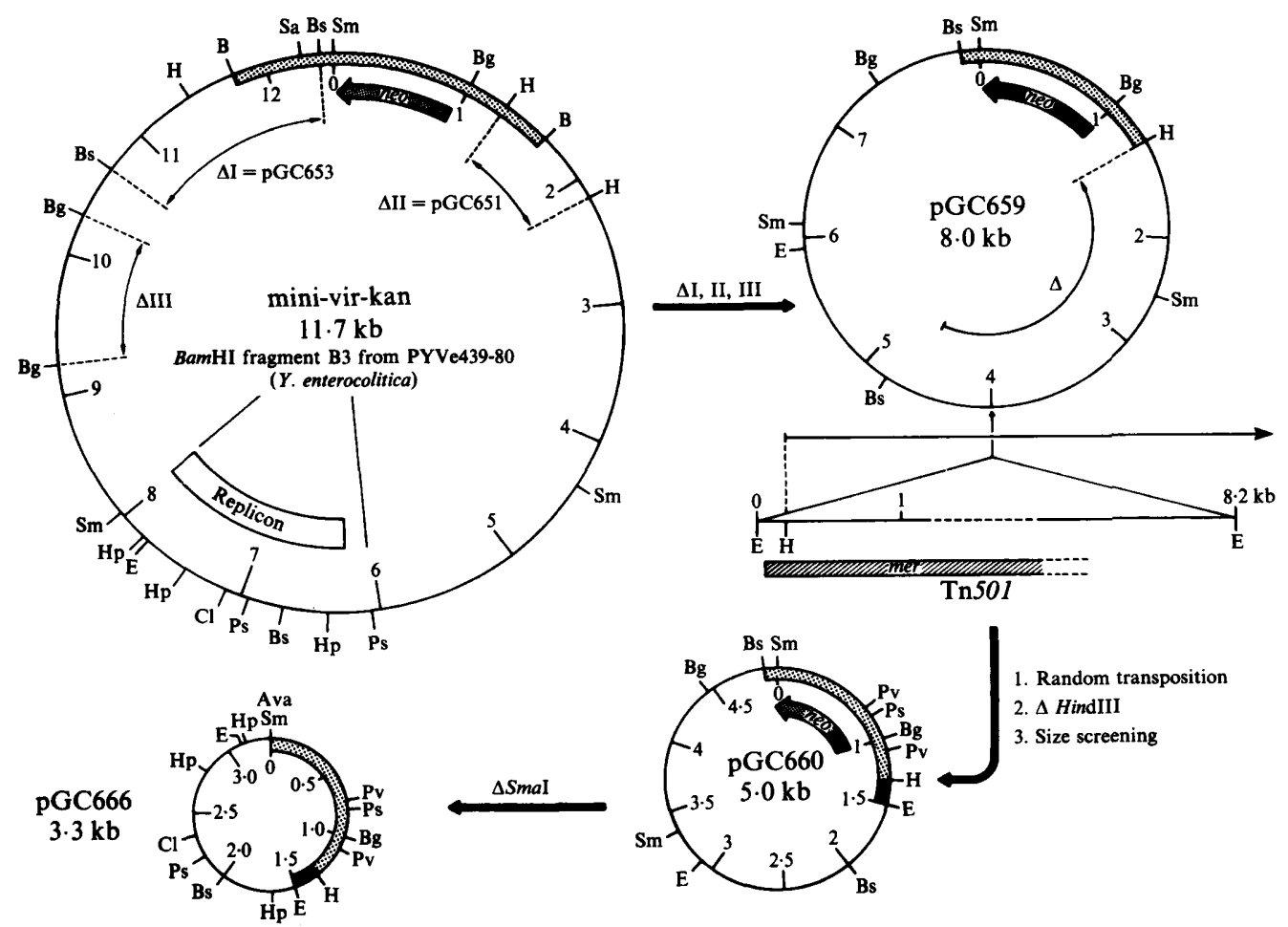

Fig. 1. Isolation of the minimal region of pYVe439-80 capable of autonomous replication ('minimal replicon'). Plasmid mini-vir-kan was reduced to pGC659 by three successive in vitro deletions $(\Delta \mathrm{I}, \Delta \mathrm{II}$, $\Delta$ III). Transposon Tn501 was inserted into pGC659 as described in the text. Plasmid DNA was extracted, digested with HindIII, ligated and used to transform E. coli C600. Plasmid pGC660 was the smallest of 37 transformants that were analysed. It was in turn reduced by in vitro deletion to give pGC666. Ava, AvaI ; B, BamHI ; Bg, BgIII; Bs, BstEII; Cl, ClaI ; E, EcoRI; H, HindIII ; Hp, HpaI ; Ps, PstI; Pv, PvuII; Sa, Sall; Sm, SmaI; neo, kanamycin phosphotransferase gene of Tn5; mer, mercury resistance gene of $\operatorname{Tn} 501$.

while both strains were transformed by pGC666, indicating that insertion of pKT279 at the EcoRI site disrupted the replication region of pYVe439-80.

We have previously presented a restriction map of a typical pYV plasmid from serogroup $9 Y$. enterocolitica strains (Laroche et al., 1984). We propose to recalibrate this map and to use the EcoRI site located in the replication region as the origin for the coordinate system (Fig. 2).

\section{Thermosensitivity of the replication function}

When grown at $28^{\circ} \mathrm{C}$ for $25-30$ generations, E. coli $\mathrm{C} 600$ loses the mini-derivatives of pYVe439-80 (mini-vir-kan, pGC653, pGC660) at frequencies ranging from $10 \%$ to $18 \%$. pGC653 was also tested at $37^{\circ} \mathrm{C}$ and $40^{\circ} \mathrm{C}$. At $37^{\circ} \mathrm{C}$ the rate of segregation was in the same range as that found at $28{ }^{\circ} \mathrm{C}$, but at $40^{\circ} \mathrm{C}$ it was greater than $99 \%$. The replication function of pYVe439-80 is thus thermosensitive. This feature is particularly relevant to the biology of the plasmid since the virulence phenotype conferred on Yersinia is strongly influenced by temperature.

Analysis of the replication function of a $p Y V$ plasmid from $Y$. pseudotuberculosis

The origin of replication of pIB1, the pYV plasmid from $Y$. pseudotuberculosis YPIII, was localized in BamHI fragment 4 by Portnoy et al. (1984). This $6.6 \mathrm{~kb}$ fragment was cloned into pBR322 to give plasmid pIB588. We constructed the restriction map of this plasmid using enzymes that were found to have sites in pGC666. Comparison of the maps of pGC666 and pIB588 shows that the series of eight sites identified in the pYV moiety of pGC666 are exactly as appear in pIB588 (Fig. 3). In order to check the distances between the sites in the two plasmids, 

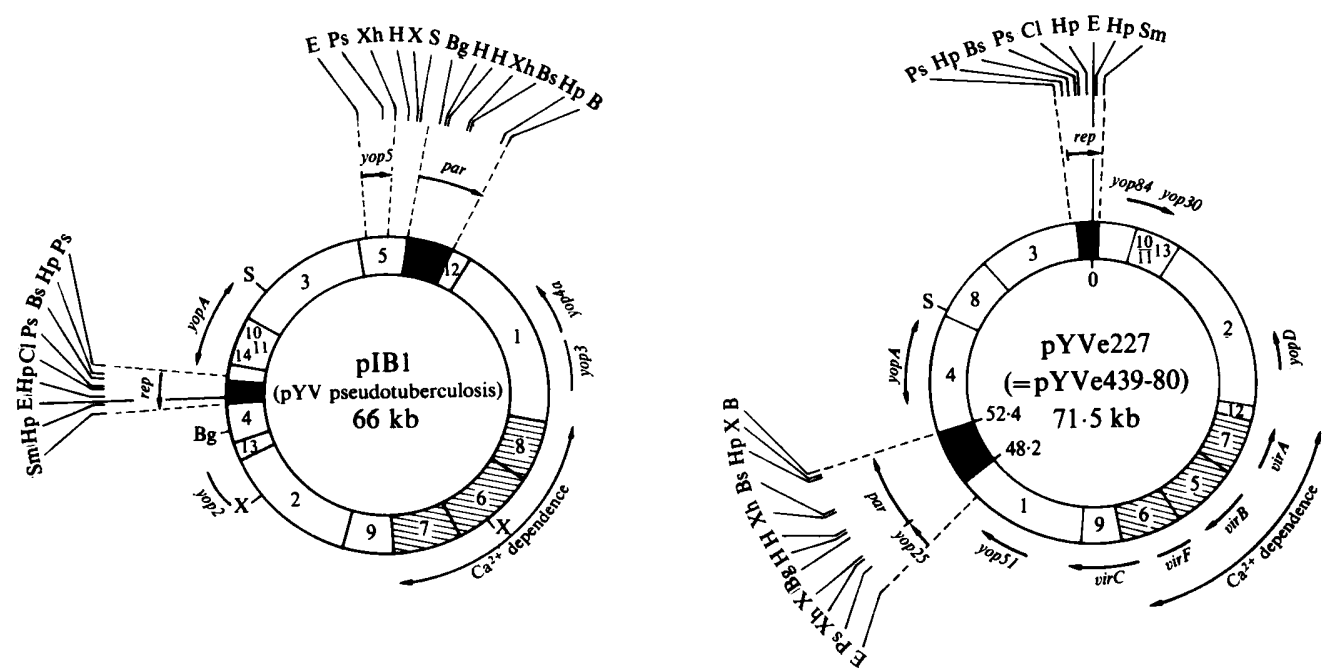

Fig. 2. BamHI restriction map of pYV plasmids pYVe227 (from Y. enterocolitica W227; indistinguishable from pYVe439-80) and pIB1 (from $Y$. pseudotuberculosis YPIII). The relative positions of the replication region (rep), partition region (par) and the region governing calcium dependence are shown. The map also shows the position of some yop genes. The restriction map of the $Y$. enterocolitica plasmid is that of Laroche $e t$ al. (1984) recalibrated by taking the EcoRI site within rep as coordinate $0 \mathrm{~kb}$. The nomenclature and positions of vir and yop genes are from Cornelis et al. (1986, $1987 a$ ). The numbers identifying yop genes correspond to the molecular mass (in kDa) of the protein encoded by the gene. The map and nomenclature of pIB1 is from Forsberg et al. (1987). yop2, yop3, yop $4 a$ and yop 5 encode proteins of $45,41,34$ and $26 \mathrm{kDa}$ respectively. yop $A$ is the gene encoding the largest YOP. The three hatched fragments are highly conserved in pYV plasmids isolated from members of the genus Yersinia. The arrows below rep and par indicate the orientations, and not transcription directions, of the genes. Arrows below vir and yop genes indicate directions of transcription. S, SalI; X, XbaI; Xh, XhoI; for abbreviations of other restriction sites see Fig. 1 .

pIB588 DNA and pGC666 or mini-vir-kan DNA were digested with PstI, HpaI, $B s t \mathrm{EII}+E c o \mathrm{RI}$ and $P s t \mathrm{I}+E c o \mathrm{RI}$ and the digests were electrophoresed in parallel (data not shown). All the fragments derived from between the PstI and SmaI sites (i.e. coordinates 6.1$8.05 \mathrm{~kb}$ of mini-vir-kan) were indistinguishable in size. Hence, we conclude that the pYV plasmids of $Y$. enterocolitica and $Y$. pseudotuberculosis share very closely related replication functions. However, the homology between fragment B3 from pYVe439-80 and fragment B4 of pIB1 does not extend outside this $1.95 \mathrm{~kb}$ region.

The BamHI restriction maps of pYV plasmids from $Y$. pseudotuberculosis and $Y$. pestis are very similar (Portnoy et al., 1984). The replication function of the pYV plasmid from $Y$.pestis O19 is located in BamHI fragment 6 (Portnoy \& Falkow, 1981). As compared to the region encoding calcium dependency, this location corresponds to that of the replication function of pIB1. It is thus likely that the pYV plasmids of $Y$. pseudotuberculosis and $Y$. pestis also share closely related replication functions.

\section{Relative orientation of the replication regions in $p Y V e 439-80$ and in $p I B 1$}

Plasmids pYVe439-80 (from Y. enterocolitica) and pIB1 (from Y. pseudotuberculosis) have homologous replication functions but these are located differently with respect to other common genes. These plasmids appear to have undergone rearrangements during their evolution from a common ancestor. In order to understand these rearrangements, it was necessary to determine the orientation of the replication regions in both plasmids. The data available for $p Y V e 439-80$ (Laroche et al., 1984) allowed us to orientate rep unambiguously on this plasmid (Fig. 2). For pIB1, the available BamHI map (Bölin \& Wolf-Watz, 1984) was not sufficient to orientate rep and the strategy outlined in Fig. 4(a) was devised. pIB1 was cleaved with SalI and XbaI. The $17 \mathrm{~kb}$ fragment was eluted from the agarose gel. This fragment contains Bam HI fragments B4, 


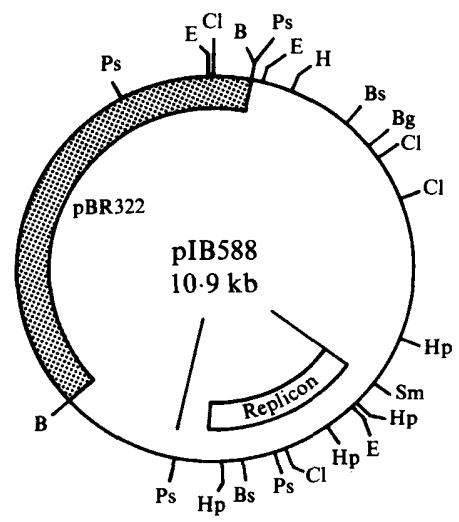

Fig. 3. Restriction map of pIB588. For abbreviations of restriction sites, see Fig. 1.
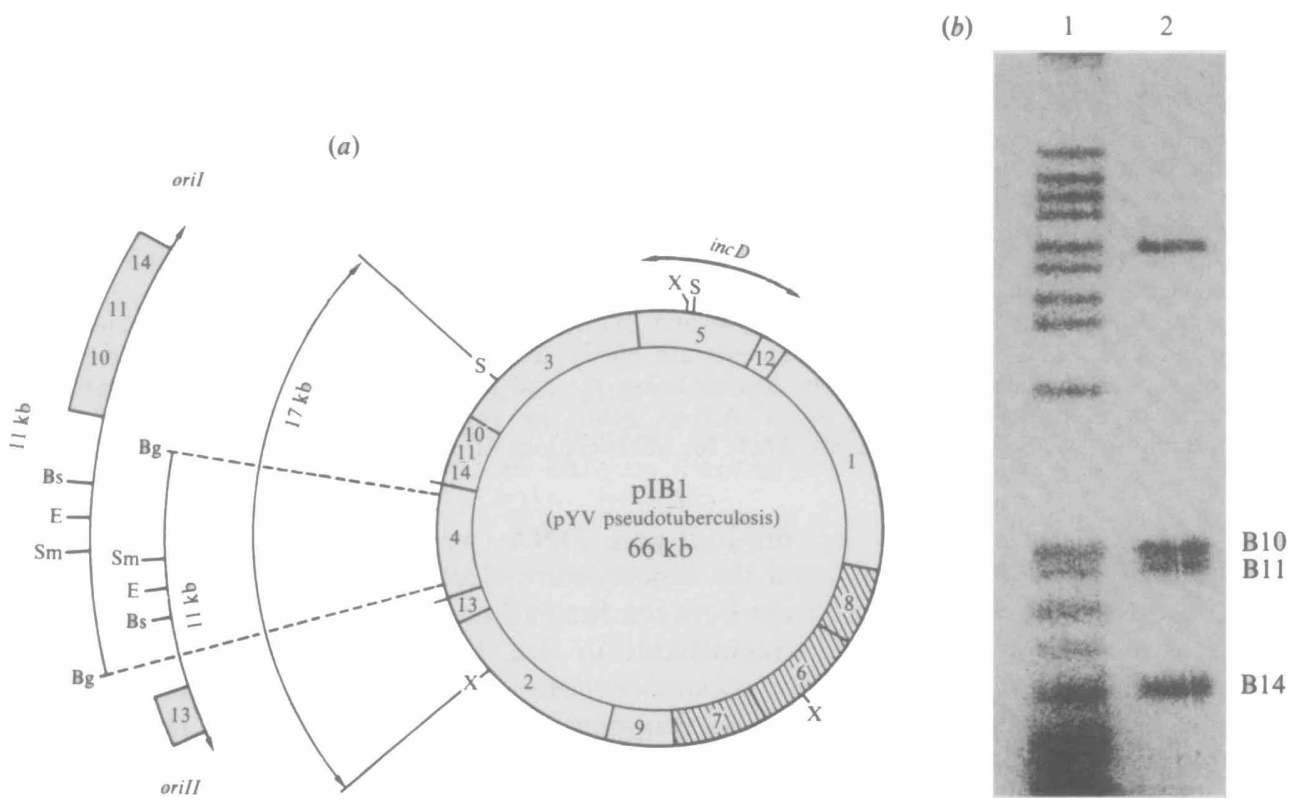

Fig. 4. Determination of the orientation of rep on pIB1. (a) Outline of the strategy (see text). The figure shows the $17 \mathrm{~kb} S a I I-X b a I$ fragment that was isolated. It also shows the two possible positions of the $B g I I I$ site and the maps of the $11 \mathrm{~kb}$ fragment that would be generated by a $B g I I$ digestion, in both cases. For abbreviations of restriction sites, see Figs 1 and 2. (b) Autoradiograph of an electrophoresis of the BamHI digest of pIB1 (lane 1) and of the $11 \mathrm{~kb}$ fragment (lane 2). Fragments were labelled terminally after digestion. B10, B11 and B14 are present in the $11 \mathrm{~kb}$ fragment.

B10, B11, B13 and B14. It is known from Fig. 3 that fragment B4 is cleaved by BglI into two fragments of $1.2 \mathrm{~kb}$ and $5.4 \mathrm{~kb}$, the latter containing rep. The $S a I-X b a I$ fragment was cleaved with $B g / I I$; this digest gave a fragment of $11 \mathrm{~kb}$ and fragments smaller than $5.4 \mathrm{~kb}$. The rep gene must be located in the $11 \mathrm{~kb}$ fragment, and the order of the sites is $B g l \mathrm{II}, S m a \mathrm{I}, E c o R I$ and BstEII (see Fig. 3). The $11 \mathrm{~kb}$ fragment was isolated and cleaved with BamHI in order to determine whether it contains $\mathrm{B} 13$ or $\mathrm{B} 10, \mathrm{~B} 11$ and $\mathrm{B} 14$. The restriction fragments were labelled terminally and run in parallel with a BamHI digest of pIB1. As shown in Fig. 4(b), this digest contained B10, B11 and B14, which implies that rep is in orientation I in pIB1. Hence the rep genes are in the opposite orientation in pIB1 and pYVe439-80 (Fig. 2). 
Like other low-copy-number plasmids, pYVe439-80 is very stably inherited at low temperature (Bakour et al., 1983). In contrast, the mini-derivatives of pYVe439-80 are lost at $28^{\circ} \mathrm{C}$ at a rate of about $10 \%$ in $25-30$ generations, suggesting that a partitioning system (Nördstrom et al., 1980) was lost during the process of reduction.

Since pYVe439-80 possesses an incD incompatibility determinant (Bakour et al., 1983) and since this determinant is involved in the maintenance of F (Phua et al., 1982; Hayakawa et al., 1985), we assumed that the incD determinant of pYVe439-80 could exert the same maintenance function. To verify this hypothesis, the largest BamHI fragment (B1) of pYVe439-80 containing incD (Bakour et al., 1983), was cloned into the unique BamHI site of pGC653. The ligation mixture was used to transform $E$. coli $\mathrm{JC} 6310\left(\mathrm{~F}^{\prime} l a c\right)$. This allowed an easy screening of the recombinant plasmid because of the incompatibility resulting from the presence of inc $D$ on both $F^{\prime} l a c$ and the recombinant plasmid. The $\mathrm{Km}^{\mathrm{R}}$ transformants giving minute colonies were restreaked on $\mathrm{MC}+$ kanamycin. Plasmids in lactose-negative clones were analysed by BamHI restriction and the relevant recombinant clone, i.e. pGC653-B1, was called pGC680.

E. coli $\mathrm{C} 600$ (pGC680) and $E$. coli $\mathrm{C} 600$ (pGC653) were subjected in parallel to 14 independent segregation experiments at $28{ }^{\circ} \mathrm{C}$. pGC653 segregated at a rate of $9.5 \pm 3.8 \%$ (mean $\pm \mathrm{SE}$ ), while pGC680 segregated at a rate of only $0.07 \%$. Thus, the insertion of the $13.8 \mathrm{~kb} \mathrm{B1}$ fragment reduced the segregation rate by a factor of 135 . Hence, we conclude that B1 encodes a partitioning system analogous to that of $F$. This system most probably involves incD.

We localized the determinant incD of pYVe439-80 in the EcoRI (coordinate $46.7 \mathrm{~kb}$ )-BamHI (coordinate $52.4 \mathrm{~kb}$ ) fragment of B1 by Southern blot hybridization (data not shown) with EcoRI fragment 5 of $F$ (called $f 5$ ), and were surprised to find that the position of these par genes in pYVe439-80 corresponded to that of the rep genes in pIB1 (see Fig. 2).

\section{Localization of the partitioning system in PIBI}

Bakour et al. (1983) showed that the pYV plasmid of a Y.pseudotuberculosis strain also belongs to the incompatibility group F1, and they speculated that this plasmid also carried an incD determinant. We localized this determinant on pIB1 by Southern blot hybridization with f5. This analysis revealed homology with fragment BamHI 5 of pIB1 (called B5) (data not shown). The latter fragment was purified and cloned into pUC9 for characterization. The map of B5 was compared to that of fragment B1 from pYVe439-80. As shown in Fig. 2, there is an identical series of 10 sites in the two fragments, the only differences being two additional SalI and HindIII sites near the centre of B5 and one additional $X b a I$ site close to the end of B1. Southern blot hybridization experiments (not shown) confirmed the homology between these regions of the two pYV plasmids. Hence, we conclude that both plasmids rely on the same partition function.

It is striking that the position of the par genes of pIB1 corresponds to that of the rep genes of pYVe439-80 (see Fig. 2). This suggests that an inversion occurred in one of the two plasmids during evolution. This hypothesis is supported by the fact that the rep genes are in opposite orientation in the two plasmids. However, the position of yopA, determined by Bölin \& WolfWatz (1984) in pIB1 and by Balligand et al. (1985) in pYVe227 can not be explained by this hypothesis. Hence, we decided to determine the relative orientation of the par genes in the two plasmids.

The orientation of fragment B1 in the map of pYVe439-80 was determined by comparison with the EcoRI, BamHI map of Laroche et al. (1984). In order to orientate fragment B5 in the map of pIB1 (Bölin \& Wolf-Watz, 1984), we carried out a BamHI digestion on the small SalI fragment isolated from this plasmid (see Fig. 4). This digest was analysed in parallel with a SalI + BamHI digest of pUC9-B5. Both digests generated the small SalI-BamHI subfragment of B5 rather than the large one (data not shown), which allowed us to orientate fragment B5 in pIB1. This orientation agrees with the respective position of the $S a l I$ and $X b a I$ sites in the map of Bölin \& Wolf-Watz (1984) and with the position of yop 5 given by Forsberg et al. (1987) (see Fig. 2). Hence, we conclude that the par regions of the two plasmids are orientated similarly in the two pYV plasmids. This result confirms that the rearrangement that occurred in these pYV plasmids did not arise simply by the inversion of a large pYV quadrant. This is also confirmed by 


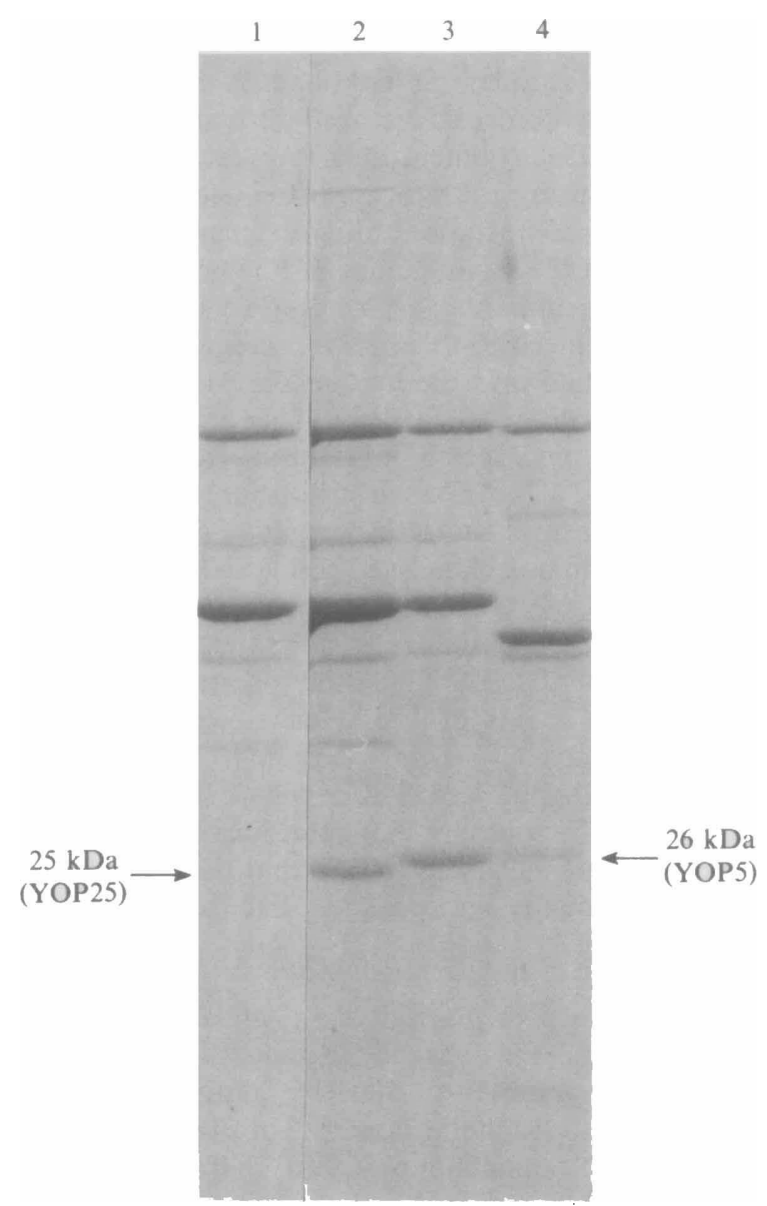

Fig. 5. SDS-PAGE of secreted proteins. Lane 1, Y. enterocolitica W22703(pGC1256); lane 2, $Y$. enterocolitica W22703(pYVe227); lane 3, Y. enterocolitica W22703(pGC1256)(pTB1); lane 4, $Y$. pseudotuberculosis YPIII(pIB1). The arrows point to the 25 and $26 \mathrm{kDa}$ proteins (called YOP25 in $Y$. enterocolitica and YOP5 in $Y$. pseudotuberculosis).

the fact that yopA seems to occupy the same locus in both plasmids (see Fig. 2). In the inversion hypothesis, yop $A$ would have been included in the inverted segment and hence would be located differently in the two maps. The orientation of yop $A$ in either plasmid is not yet known.

The yop regulons of the $p Y V$ plasmids from $Y$. enterocolitica and $Y$. pseudotuberculosis are functionally related

The pYV plasmids from $Y$. enterocolitica and $Y$. pseudotuberculosis govern the synthesis and secretion of YOP proteins, which are encoded by pYV genes called yop genes. The production of these proteins requires the activity of at least four other plasmid genes, vir $A, \operatorname{vir} B, \operatorname{vir} C$ and virF (Cornelis et al., 1986, 1987a). We wanted to determine whether a yop gene from $Y$. pseudotuberculosis could be expressed in $Y$. enterocolitica.

On plasmid pYVe439-80, gene yop 25, encoding YOP25 $(25 \mathrm{kDa})$, maps around coordinate $47 \mathrm{~kb}$ (Cornelis et al., 1987a), i.e. close to incD. In $Y$. pseudotuberculosis, the gene encoding YOP5 (26 kDa) maps in BamHI fragment 5 (Forsberg et al., 1987). According to the restriction maps presented in Fig. 2, the region that appears to be conserved around par in both species includes this yop gene. The BamHI-EcoRI fragment of pIB588 was cloned on pTM100, a mobilizable derivative of pACYC184 ( $\mathrm{T}$. Michiels, unpublished construction), and the 
recombinant plasmid, pTB1, was introduced into $Y$. enterocolitica W22703(pGC1256). The latter plasmid is a derivative of pYVe227 mutated in yop25. We analysed the profile of the proteins secreted by W22703(pGC1256)(pTB1). As shown in Fig. 5, this strain of $Y$. enterocolitica clearly secreted YOP5. Hence the $Y$. pseudotuberculosis gene was expressed and its product was secreted in this $Y$. enterocolitica background.

Thus, the virulence regulon present on pYV plasmids from $Y$. enterocolitica and $Y$. pseudotuberculosis is functionally conserved in spite of the fact that some yop genes evolved and suffered internal translocations. This evolution is illustrated by the fact that the homologous genes yop 25 (from Y. enterocolitica) and yop 5 (from Y. pseudotuberculosis) encode proteins of 25 and $26 \mathrm{kDa}$ respectively and map differently on the pYV plasmids.

\section{Concluding remarks}

The pYV plasmids from $Y$. enterocolitica and $Y$. pseudotuberculosis possess the same replication and partition functions and they carry functionally analogous yop regulons. They appear to have originated from a common ancestral plasmid as a result of structural rearrangements.

We thank G. Balligand for participating in the experiments designed to reduce the size of pGC659. We are grateful to D. Helinski for providing oriT of RP4, to T. Michiels for providing pTM100 and to H. Wolf-Watz for providing pIB1 and pIB588. We also thank G. Gobert for typing this manuscript and T. Michiels and M. P. Sory for discussions and criticism.

This work was supported by grants from the Belgian FRSM (Fonds de la Recherche Scientifique Médicale Convention 3.4514.83) and SPPS (Services de la Programmation de la Politique Scientifique).

\section{REFERENCES}

Bakour, R., Laroche, Y. \& Cornelis, G. (1983). Study of the incompatibility and replication of the $70-\mathrm{kb}$ virulence plasmid of Yersinia. Plasmid 10, 279-289.

Bakour, R., Balligand, G., Laroche, Y., Cornelis, G. \& WAUTERS, G. (1985). A simple adult-mouse test for tissue invasiveness in $Y$. enterocolitica strains of low experimental virulence. Journal of Medical Microbiology 19, 237-246.

Balligand, G., Laroche, Y. \& Cornelis, G. (1985). Genetic analysis of virulence plasmid from a serogroup 9 Yersinia enterocolitica strain: role of outer membrane protein P1 in resistance to human serum and autoagglutination. Infection and Immunity 48, 782-786.

Beck, E., Ludwig, G., Auerswald, E. A., Reiss, B. \& SCHALLER, H. (1982). Nucleotide sequence and exact localization of the neomycin phosphotransferase gene from transposon Tn5. Gene 19, 327-336.

Bölin, I., Norlander, L. \& Wolf-Watz, H. (1982). Temperature-inducible outer-membrane protein of Yersinia pseudotuberculosis and Yersinia enterocolitica is associated with the virulence plasmid. Infection and Immunity 37, 506-512.

BöLIN, I. \& WoLF-WATZ. H. (1984). Molecular cloning of the temperature-inducible outer membrane protein 1 of Yersinia pseudotuberculosis. Infection and Immunity 43, 72-78.

Brown, N. L., Choi, C. L., Grinsted, J., Richmond, M. H. \& WhiteheAD, P. R. (1980). Nucleotide sequences at the ends of the mercury resistance transposon, Tn501. Nucleic Acids Research 8, 1933-1945.

CoRnelis, G. \& Colson, C. (1975). Restriction of DNA in Yersinia enterocolitica detected by recipient ability for a derepressed R factor from Escherichia coli. Journal of General Microbiology 87, 285-291.
Cornelis, G., Sory, M. P., Laroche, Y. \& Derclaye, I. (1986). Genetic analysis of the plasmid region controlling virulence in Yersinia enterocolitica $O: 9$ by Mini-Mu insertions and lac gene fusions. Microbial Pathogenesis 1, 349-359.

Cornelis, G., Vanoothegem, J.-C. \& Sluiters, C. $(1987 a)$. Transcription of the yop regulon from $Y$. enterocolitica requires trans acting $\mathrm{pYV}$ and chromosomal genes. Microbial Pathogenesis 2, 367-379.

Cornelis, G., LARoche, Y., Balligand, G. \& SoRY, M. P. (1987b). Yersinia enterocolitica, a primary model for bacterial invasiveness. Reviews of Infectious Diseases 9, 64-87.

de la Cruz, F. \& Grinsted, J. (1982). Genetic and molecular characterization of Tn21, a multiple resistance transposon from R100-1. Journal of Bacteriology 151, 222-228.

FERBER, D. M. \& Brubaker, R. R. (1981). Plasmids in Yersinia pestis. Infection and Immunity 31, 839 841 .

Forsberg, A., Bölin, I., Norlander, L. \& WolfWATZ, H. (1987). Molecular cloning and expression of calcium-regulated, plasmid-coded proteins of $Y$. pseudotuberculosis. Microbial Pathogenesis 2, 123-137.

Gemski, P., Lazerre, J. R. \& Casey, T. (1980a). Plasmid associated with pathogenicity and calcium dependency of $Y$. enterocolitica. Infection and Immunity 27, 682-685.

Gemski, P., Lazerre, J. R., Casey, T. \& Wohlieter, J. A. $(1980 b)$. Presence of a virulence-associated plasmid in Yersinia pseudotuberculosis. Infection and Immunity 28, 1044-1047.

Goguen, J. D., Yother, J. \& Straley, S. C. (1984). Genetic analysis of the low calcium response in Yersinia pestis $\mathrm{Mu}$ dl(Aplac) insertion mutants. Journal of Bacteriology 160, 842-848. 
Hayakawa, Y., Murotsu, T. \& Matsubara, K. (1985). Mini-F protein that binds to a unique region for partition of Mini-F plasmid DNA. Journal of Bacteriology 163, 349-354.

HeesemanN, J., Algermissen, B. \& Laufs, R. (1984). Genetically manipulated virulence of Yersinia enterocolitica. Infection and Immunity 46, 105-110.

Laroche, G., Van Bouchaute, M. \& Cornelis, G. (1984). A restriction map of virulence plasmid pVYE439-80 from a serogroup 9 Yersinia enterocolitica strain. Plasmid 12, 67-70.

Maniatis, T., Fritsch, E. F. \& Sambrook, J. (1982). Molecular Cloning, a Laboratory Manual. Cold Spring Harbor, NY: Cold Spring Harbor Laboratory.

Nördstrom, K., Molin, S. \& AagaARd-Hansen, H. (1980). Partitioning of plasmid R1 in Escherichia coli. Plasmid 4, 215-227.

Phua, S. H., Bergquist, P. L. \& Lane, H. E. D. (1982). Effects of $T n 5$ insertion in the incD region on mini-F maintenance and polypeptide synthesis. Molecular and General Genetics 188, 353-355.
Portnoy, D. A. \& Falkow, S. (1981). Virulenceassociated plasmids from Yersinia enterocolitica and Yersinia pestis. Journal of Bacteriology 148, 877-883. Portnoy, D. A., Wolf-Watz, H., Bölin, I., BeEder, A. B. \& FALKow, S. (1984). Characterization of common virulence plasmids in Yersinia species and their role in the expression of outer membrane proteins. Infection and Immunity 43, 108-114.

Straley, S. C. \& BowMer, W. S. (1986). Virulence genes regulated at the transcriptional level by $\mathrm{Ca}^{2+}$ in Yersinia pestis include structural genes for outer membrane proteins. Infection and Immunity 51, 445-454.

TAlmadge, K. \& Gilbert, W. (1980). Construction of plasmid vectors with unique $P$ st I cloning sites in a signal sequence coding region. Gene 12, 235-241.

ZinK, D. L., Feeley, J. C., Wells, J. G., VANDERZANT, C., ViCKeRY, J. C., ROOF, W. D. \& O'Donovan, G. A. (1980). Plasmid-mediated tissue invasiveness in Yersinia enterocolitica. Nature, London 283, 224-226. 